\title{
Do corporate social responsibility practices of firms attract prospective employees? Perception of university students from a developing country
}

\author{
Samuel Nana Yaw Simpson ${ }^{*}$ and Eunice Kafui Aprim
}

\begin{abstract}
This paper primarily explores the relevance of Corporate Social Responsibility Practices (CSRP) of organizations in attracting university students (prospective employees) in developing countries. The study employed a survey strategy, where questionnaires were administered to 600 final-year undergraduate students at the premier Business School in Ghana out of which 500 were returned. Though results show relatively low level of CSR awareness, the respondents agreed that the elements of an organisation's CSRP, whether economic, social or environmental, played a determining role in their preference for a particular organisation (employer). Also, the disclosure of CSRP by an organisation is relevant in their choice of an employer. The findings suggest the need for organisations to take cognizance of the growing interest of prospective employees in working for organisations that engage in CSR activities and disclosures. Furthermore, educational institutions must be deliberate in developing CSR orientation of students to engage in the systematic processing of CSR related information through Education for Sustainable Development (ESD).
\end{abstract}

Keywords: Corporate social responsibility, Prospective employees, Attraction to an organisation, Ghana

\section{Introduction}

Research on job-related choices has revealed several factors that influence a prospective employee's (including students) decision to work with or not to work with a particular organisation. Such factors include value congruence between the individual and the organisation (Yang \& Yu, 2014), the level of Person-Organisational (PO) fit and the nature of employee benefits that each organisation offers (Duda, 2014), recruiter-friendliness (Goltz \& Giannantonio, 1995), working conditions and fringe benefits (Teo \& Poon, 1994), and many more.

Many of the studies on job-related choices have been location-specific, focusing on countries like Singapore (Teo \& Poon, 1994; Yang \& Yu, 2014), India (Gokuladas, 2010), the Czech Republic (Duda, 2014) and South Korea; Lee et al., 2013), with mixed findings, which are difficult to generalize (Hong \& Kim, 2017). Other studies have also considered how issues like CSR and CSR

\footnotetext{
* Correspondence: snysimpson@ug.edu.gh

Department of Accounting, University of Ghana Business School, Legon, Accra, Ghana
}

orientations attract or retain employees (e.g., Turban \& Greening, 1997; Turban, et al., 1998; Greening \& Turban, 2000; Lee et al., 2013; Duarte, et al., 2014; Barrena- Martinez et al., 2015; Story, et al., 2016; Jones et al., 2016). These developments have resulted in the emergence of a new CSR taxonomy: CSR and Organizational Psychology (Jones, et al., 2017).

There are issues with the above-mentioned studies that are worth noting. First, many of the studies report the perspective of employers, existing employees, and desperate job seekers who may settle for any job (Greening \& Turban, 2000; Turban, et al., 1998; Turban \& Greening, 1997; Bhattacharya et al., 2008; Lee et al., 2013; Jones et al. , 2017; Odumeru, et al., 2014). Also, many questions on organisational attraction, particularly from the perspectives of prospective employees remain unanswered (Gomes \& Neves, 2011). Secondly, Evans and Davis (2011) report that the understanding of CSR positively influences the attraction of individuals with a high-value orientation to organisations. However, many of the existing studies only assume that job seekers understand the concept of 
CSR. Thirdly, the studies have been mostly based on evidence from developed countries and industries such as hospitality, textile and apparel and construction (see also Cooke \& He, 2010). This is consistent with findings of the study reported in Tilt (2016) which mentioned the failure of many CSR studies to investigate contextual factors, particularly, in developing countries. There is, therefore, the need for studies based on evidence from developing countries as well as particular industries and sectors that have not been covered (Hong and Kim, 2017). Indeed, Tilt (2016) advocates for studies based in developing countries since such countries constitute the majority of the world's population, with their unique cultural, social, environmental and political issues (United Nations 2013). Tilt (2016) concludes that context is crucial in understanding CSR practices and their implications. In support of this view, Hong and Kim (2017) report that Korean job-seekers are attracted to jobs with US firms than with Chinese firms, but CSR practices have indicated significant implications for application intentions toward Chinese firms, compared to US firms.

In response to the above, this study explores the relevance of corporate social responsibility practices (CSRP) of organisations in attracting prospective employees in a developing country, Ghana. Unlike existing studies, this work uses final year undergraduate business students as prospective employees, rather than job seekers who may be desperately looking for employment and may settle for any job (Odumeru, et al., 2014). It first investigates the level of awareness and understanding of CSR issues (Evans \& Davis, 2011) among prospective employees in a developing country, before exploring how CSR practices influence organisational attraction. Specifically, this study attempts to investigate the level of understanding of CSR among prospective employees; to explore the factors that attract prospective employees to an organisatio as well as the relevance of CSR initiatives and disclosures in attracting prospective employees to an organisation.

This study therefore shows the need for organisations to take cognizance of the growing interest of prospective employees in working for organisations that undertake CSR activities and disclosures (e.g., Bhattacharya et al., 2008; Lee et al., 2013; Meister, 2012). It also suggests the need for educational institutions to be deliberate in developing the CSR orientations of students and their personal values through CSR education and Education for Sustainable Development (ESD), to enable students engage in the systematic processing of CSR related information (Lagrell, 2009; Gross and Nakayama, 2010). At the government level, the study calls for a discussion on the need to formalize some minimum CSRP by organisations within developing countries. This is particularly important, considering the recent launch of a National
CSR policy for Ghana (GNA, 2016) where organisations were encouraged to voluntarily undertake CSR activities and report accordingly.

The next section reviews both empirical and theoretical literature on the subject area. This is followed by descriptions and justifications for the research methods and approaches adopted for the study. The penultimate section presents and discusses the results of the analysis of the data collected whilst the final section highlights the key findings of the study and the possible conclusions.

\section{Literature review}

This section covers literature on the CSR concept, the nature and forms that it may take as well as the existing guidelines on CSR practice. The section also explores the relevance of ESD in propagating the concept of CSR in Higher Education.The section further reviews the empirical literature on the factors that attract employees to an organisation, particularly, the corporate social responsibility practices. Finally, some theories relevant in explaining the phenomenon under study are reviewed.

\section{Definition, nature and guidelines on CSR}

CSR is considered as a broad term, such that an exhaustive or conclusive definition remains non-existent. Most of the attempts to define CSR address only an aspect of it (Carroll \& Shabana, 2010; Dahlsrud, 2008; Ghobadian et al., 2015; Danilovic et al., 2013; Sprinkle \& Maines, 2010). For instance, an earlier definition of CSR by Carroll (1979) highlights four facets of CSR, which include economic, legal, ethical, and discretionary. Other definitions focus on the Three Basic Models of Corporate Social Responsibility: CSR Pyramid, Intersecting Circles, and Concentric Circles (Geva, 2008); and others, the five dimensions of CSR: philanthropic, environmental, social, stakeholder and voluntariness dimensions (Dahlsrud, 2008).

Over the years, Dahlsrud's dimensions of CSR have received worldwide acceptance and have been said to be more inclusive of several factors. Also, related concepts such as corporate social performance (CSP), corporate social orientation (CSO), and corporate social responsibility disclosure (CSRD) have been introduced. While CSP is concerned with how well an organization is doing with respect to its CSR initiatives (Wood,1991), CSO has to do with how managers and stakeholders in general view CSR (Smith, et al., 2004), and CSRD relates to the communications of CSR initiatives (see e.g., Tilt, 2001).

Despite the foregoing, CSR practices are influenced by contextual factors, causing it to vary at the individual, collective, and country levels (Lee et al., 2013; Tilt, 2016) and to be subjected to several manipulations (Dubbink, et al., 2008). Indeed, the concept varies in relation to underlying meanings and applications (Matten \& Moon, 
2008). This perhaps explains the emergence of several guidelines such as the UN Global Compact, the Global Reporting Initiative (GRI) guidelines, ISO Standards, and the AccountAbility (AA) guidelines. These guidelines render some form of regulation, applications and credibility to CSR disclosures by organisations, although a number of them remain voluntary. Over the years, the GRI guidelines have gained so much prominence that it has come to be considered the default guideline for many organisations (KPMG, 2015).

Also, there is a growing call for CSR education under the tag, ESD to minimise the variations in the understanding and conceptualisation of CSR (UNESCO, 2009). A notable development is the United Nations declaration of a decade of Education for Sustainable Development 2005-2014, which has resulted in what is commonly referred to as Education for Sustainable Development (UNESCO, 2009, 2014).

\section{Education for sustainable development (ESD) and CSR}

Education for Sustainable Development (ESD) has been recognised in recent years as a key tool for promoting awareness and developing social and environmental values, as well as influencing behaviours to achieving sustainable futures (Pavlova, 2009; UNESCO, 2009, 2014). It is seen as deliberate effort to introducing into the conscience and thinking of people the concepts and principles of sustainability (Barth et al., 2007; Rieckmann, 2012; Loranzo et al., 2013; Wals, 2014). While this development is seen by some scholars as a significant transformation in the global perspective on education in matters regarding sustainability issues, other scholars have perceived it to be a logical and justifiable transition to a broader spectrum, emanating from the issue of CSR (Wade \& Parker, 2008; Pavlova, 2012; Idowu et al., 2015). Indeed, scholars argue that ESD is one of the potent tool for the understanding the concept of CSR (Ramasamy, \& Ting, 2004; Osagie et al. 2016). However, literature exploring the concept from developing countries context is scanty (Manteaw (2012).

Also, from literature, the responsibility for ESD falls on the entire public including governments, businesses and civil society organisations (Gross and Nakayamah, 2010). However, educational institutions, particularly, institutions of higher learning have been identified as crucial in ESD (UNESCO, 2009; Barth et al., 2007; Rieckmann, 2012; Lozano, et al., 2013). Though many universities are pursuing the ESD agenda, the concepts and its underpinning principles are said to be still comparatively new to several universities in both developed and developing countries (Jones, Selby, \& Sterling, 2010; UNESCO, 2014; Lozano, et al., 2013; Fernández-Sánchez, et al., 2014).

In the specific case of developing countries, it is argued that the advancement of ESD is stifled by policy issues (e.g. Gross and Nakayamah, 2010; Feinstein et al., 2013) and pedagogical issues (Manteaw, 2012). For instance, Feinstein et al. (2013) highlight that often times, educational policies may not be championed by governments, thus making it voluntary for other authorities (such as leaderships of educational institutions and non-governmental organisations) regarding the advancement of ESD in school curricula and in communities. Manteaw (2012) concludes that the elements of ESD appears non-existence in most educational policies and practices in Africa since many institutions and individuals have little knowledge and understanding of role of education in the pursuit of sustainable development. Fernández-Sánchez, et al., (2014) recommend the need for ESD to be an accreditations issue, thus, encourage mandatory compliance.

The foregoing issues motivate the current study to among other things investigate the awareness and understanding of sustainability related issues among final year university students in a developing country. The study further explores how awareness of sustainability issues serve as organisational attractions.

\section{Organisational attractiveness}

Organisation or employer attraction has generally been seen as the factors which influence the choice of one organisation over another for employment. From the review of extant literature, organisation attraction includes the means of getting a job seeker to view an organization as a positive place to work (Turban \& Greening, 1997); and the extent to which the perceived benefits interest a job seeker to make him pursue an employment opportunity with an organisation (Berthon et al., 2005; Cable \& Turban, 2003). Employer attraction also refers to 'the way employers strategically attempt to exploit their strengths in order to attract applicants' (Gomes \& Neves, 2011: 684).

From the definitions, it is clear that attraction to an organisation is an implicit force that moves a prospective employee to decide to work for one organisation over another based on some explicit activities of that organisation, or based on certain characteristics the organisation exhibits.

Though the factors of attractions may vary at the different stages of the recruitment process (Gomes \& Neves, 2011), they can be classified as those that are job-related, those that have to do with organizational attributes and image, those that involve the attitude of recruiter, and finally those that have to do with individual preferences and expectations (Turban \& Keon, 1993; Teo \& Poon, 1994; Aiman-Smith, et al., 2001; Lievens, et al., 2001; Chapman, et al., 2005; Gomes \& Neves, 2011). For instance, Turban and Keon, (1993) reported that although organisational attributes such as reward systems, decision-making processes (centralized or decentralized), and the size of the organisation may attract talent, results are mixed. Also, Teo and Poon 
(1994) identified Ten Job Factors which include pay, fringe benefits, working conditions, managerial quality and relationships, long-term career prospects, responsibility given, authority, involvement in decision making, marketability and job security. Other authors reported that the attitude of the recruiter, being friendly or otherwise, perceptions of prospective employee on the recruiting process, recruiter demographics, perceived fit, and hiring expectancies (Goltz \& Giannantonio, 1995; Turban et al., 1998; Chapman, et al., 2005) can also serve as an attraction. Indeed, a prospective employee may make inferences on the nature of the working environment of that organisation through the attitude of the recruiter. For instance, a friendly recruiter may mean a better and friendlier environment to work in, whereas an unfriendly recruiter may also imply a strict and hostile environment of work.

Chapman et al., (2005) reported that job and organisational characteristics, recruiter behaviours, perceptions of the recruiting process, perceived fit, and hiring expectancies, and not the demographics of recruiter are what contribute to the organisational attraction. Similar to the work of Turban and Keon (1993), Lievens et al., (2001) focused on organisational attributes such as size of organisation, geographical dispersions (level of internationalisation), pay mix, and level of centralisation or decentralisation in decision making. They reported that except the level of decentralisation factor, which attracts talents, the rest were negatively related, contrary to the findings of Turban and Keon, (1993). In fact, the results showed that organisations that are large and mediumsized, with decentralised decision making, and are multinational in nature are more attractive to prospective employees. Also, Aiman-Smith et al., (2001) focused on two job factors: pay and promotion, and two organizational image factors: lay-off policy and ecological rating. They reported that ecological rating is the strongest organizational attraction, and pay strongly predicted job pursuit intentions.

Indeed, the above factors were identified mainly in the context of developed countries and from the perspective of job applicants with high levels of job choice (Smith, et al., 2004). They added that, in the case of the latter, a prospective employee may consider other factors as such CSP as the organizational attraction.

This study contributes to the literature by focusing on all the factors afore-mentioned in a single study, and from the perspective of prospective employees in a developing country.

\section{CSR and Organisational attractiveness}

There have been earlier studies suggesting that a firm's corporate social performance influences organisational attractiveness (Strand, et al., 1981; Greening \& Turban,
2000; Turban \& Greening, 1997). For instance Strand, et al., (1981) reported that job seekers are attracted to organisations based on their policies relating to remunerations, personal development, environmental practices and fair employment practices. In other studies, companies were selected, controlling for organisation size and firm profitability, and students were made to rate them according to their reputation and attraction. The results gave an indication that CSRP may be a source of competitive advantage in attracting applicants (Turban \& Greening, 1997). Greening and Turban (2000) also reported that firms create a form of competitive advantage when they are perceived to be attractive to work for, and having a positive CSR reputation makes that attraction possible.

However, the above studies were based on hypothetical organisations. Later studies have adopted other research strategies (the use of questionnaires) in an effort to generalise findings. For example, Backhaus et al., (2002) added that potential job seekers in the assessment of company values focus on their CSRP. They also explained that CSR is important in various job search stages and the level of importance placed it on may vary at different stages. They reported that CSR is particularly important where a decision has to be made to take a job offer. They also indicated some aspects of CSR are most important in attraction, such as environment, community relations, product issues, employee relations and diversity.

Duarte, et al., (2014) found that socially responsible practices of an organisation positively influence the perception of organization attraction, but practices toward employees and in economic areas attract participants more than practices to the benefit of community and the environment. Also, Barrena- Martinez et al. (2015) report that social factors attract college graduates than personal factors. Dividing CSR practices into internal and external, Story, et al. (2016) report that internal CSR practices are positively related to both organisational attraction and reputation, but external CSR practices positively stimulate organisational attractiveness through the reputation of organisations.

The above studies assume that prospective employees are aware and understand the concept of CSR, but Evans and Davis (2011) highlight that, the understanding of CSR has a positive impact on attracting individuals with high-value orientation, hence the need for some form of CSR education. So, this adds to the existing study by first investigating the understanding of CSR by prospective employees before exploring the relevance of CSR in organisational attraction.

\section{Theoretical underpinnings}

A number of theories support the claim that CSR is desirable by most stakeholders and can attract prospective 
applicants to organisations. The notable theories include Legitimacy Theory; The Social Identity Theory; The Signalling Theory; The Stakeholder Theory; and The Person-Organisation (PO) Fit and the Stewardship Theory. The Legitimacy theory asserts that for an organisation to be accepted by a society, it must engage in activities that are accepted by that society (Deephouse \& Carter, 2005; Bebbington, et al., 2008). This goes beyond the legal requirements of an organisation and may merit the organisation by attracting both customers and highly qualified prospective employees. This centres on gaining approval from the society (Tilling, 2004), so employees are likely to be attracted to organisations whose actions are acceptable by the society.

The Signalling Theory, on the other hand, asserts that organisations send a form of signal of what actually occurs internally to its stakeholders who look out for such signals as an indication of what happens in within (Connelly et al., 2011). These signals and signs inform how they view or approach the organisation (Bergh et al. , 2014; Jones, et al., 2009). The signalling theory avows that an organisation's engagement in CSRP can also be viewed by prospective applicants as representative of the kind of working environment that exists in the organisation. This can, therefore, inform their organisational choice (attracting them).

The concept of PO-fit remains one of the underlying factors that attract prospective employees to an organisation. Several authors have employed it to test for organisational attraction (Jones et al., 2009; Sekiguchi \& Huber, 2011; Yang \& Yu 2014). PO-fit goes beyond employment benefits, and it has to do with how the employee sees the organisation as an extension of himself or herself. It connotes a perceived alignment of an individual's goals and values to that of an organisation and therefore makes the organisation attractive to the prospective employee (Sekiguchi \& Huber, 2011).

Similar to the concept of PO-fit is the Social Identity Theory. It is about how individuals identify who they really are based on the nature of the group or organisation they find themselves in (Huddy, 2001; Hornsey, 2008). This connotes the idea that prospective employees believe their choice of organisation gives an indication of who they truly are and what they believe in (Highhouse et al. 2007). This makes their choice of organisation a deliberate one (Terry et.al 1999).

The Stewardship theory essentially communicates a stance of guardianship and trust, and a willing assumption of a responsibility for the success of an activity or an entity, or the achievement of an identified common goal (Davis, et al., 1997; Eddleston \& Kellermanns 2007). It has been considered in some literature as the antithesis of the Agency theory which presents a more human face as an explanation of the influence of the actions that boards and managers take (Eddleston \& Kellermanns, 2007). The stewardship theory recognises that boards, individuals and managements are motivated by non-financial and nonselfish interests to perform the activities they do. In relation to CSR, McWilliams et al., (2006) argue that some companies engage in CRS practices as a result of their perspective of being stewards of the environment in which they work.

Relating the above theories to the objectives of this paper, the principles of PO-fit and Social Identity Theory appear most useful as other theories such as the Legitimacy Theory, Stakeholder Theory, Stewardship Theory and Signaling Theory may be most suitable for studies focusing on the perspectives of employers.

\section{Methodology}

\section{Research strategy and method}

There are a number of research strategies to employ in any research. According to Yin (2003), any strategy could be applied to any form of research, be it an exploratory, a descriptive or an explanatory study. Some of such strategies including experiments, case studies and surveys. This study employed a survey strategy, where data was gathered through self-administered questionnaires to prospective employees using convenience sampling of final year undergraduates from the University of Ghana Business School (UGBS) as prospective employees. The choice of the University of Ghana Business School is based on the fact that it is the largest and oldest public university in Ghana, and produces a great number of prospective employees into the job market. ${ }^{1}$

\section{Data collection tool and analysis}

The data collection tool was a questionnaire prepared based on extant literature, attempting to synthesize all the factors that were raised. Aspects of the questionnaire were prepared based on the GRI guidelines, which has been described as the most comprehensive guide in the area of CSR disclosures (KPMG, 2015). A questionnaire was used due to its ability to collect data from large and different respondents within a very short time.

The questionnaire covered four (4) areas: demographic information; awareness and definition of CSR; organizational attraction factors; CSR disclosure and organisational attraction. The questions were mainly close-ended. Also, some of the questions were coded on the scale of one to seven, with one being the lowest and seven being the highest. With regards to the section on the definition of CSR, respondents were asked to tick as many terms as applicable since there is no universally accepted definition of CSR. Also, to explore the relevance of CSR disclosures as organisational attractiveness, elements in the GRI guidelines (Global Reporting Initiative (GRI) G4, 2016) were adopted. Under the GRI guidelines, 43 relevant CSR items 
were identified under 3 main headings, namely, economic, environmental and social with 4 sub-headings; Labour Practices and Decent Work, Human Rights, Society, and Product Responsibility In all of these, respondents were to choose from a scale of 1 to 7 with 1 representing not relevant and 7 representing the most relevant.

Finally, to ensure validity and reliability of the research instrument, a pilot study was undertaken and it was found that some of the CSRP items as indicated in the guidelines were difficult to understand, so some questions were modified.

With regards to data analysis, the questionnaires were collected, sorted and incomplete questionnaires were taken out. The data was descriptively analysed, where means, standard deviations, frequencies and percentages were generated. The results were subsequently presented along the objectives of the study, and discussed in relation to extant literature'.

On a whole, a total of 600 questionnaires were administered and 500 were returned, representing a response rate of about $83 \%$. In analysing the data obtained, certain assumptions were made:

1. The prospective employee has several job offers and has the luxury of choosing one over another.

2. The final year student opting to work for an organisation and not to be self-employed.

\section{Presentation and discussion of results}

In addressing the objectives of the study, the authors sought to first ensure that the respondents had fair knowledge and understanding of the concept of CSR. This was followed by an analysis of responses based on the factors, including CSR activities, identified in the literature as influencing the choice of one organisation over another. Finally, responses on the influence of CSR disclosures based on the GRI were analysed independently.

\section{Awareness and understanding meaning of CSR by students}

Studies show that awareness and understanding of the CSR concept may influence organisational attractiveness (Evans \& Davis, 2011). So, this study first sought to ascertain the level of CSR awareness among prospective employees, and results showed that majority (52\%) have heard of CSR and fairly understand it, whereas the remaining $48 \%$ had little or no knowledge as shown in Table 1. To further explore their understanding of the concept, students were asked to indicate the appropriateness of some terms associated with CSR in defining that concept. Results, as shown in Table 2, indicate that a majority of respondents defined CSRP as a commitment to the public, communities, and overall society.
Table 1 Awareness CSR

\begin{tabular}{ll}
\hline Heard of CSR & Response Rate \\
\hline Yes, I have heard and fairly understand it. & $52 \%$ \\
Yes, I have heard of it and understand a little. & $30.4 \%$ \\
No, never heard of it. & $10 \%$ \\
Yes, I have heard of it but don't understand it. & $7.6 \%$ \\
\hline
\end{tabular}

This is followed by environmentally friendly activities and ethical conduct. The others represent a fair concern or definition for the respondents. Interestingly, respondents considered 'making profits' as the least way of defining CSR. This simply means that majority of the respondents agreed with Carroll and Shabana (2010) who viewed CSRP as one that concerns environmentally friendly activities, commitment to employees, the public, communities, and the overall society.

Though the above results indicate a satisfactory awareness (52\% of the respondents) and understanding of CSR by respondents to enable them to make informed choices, there is the need for a comprehensive study on CSR education, to among other things, investigate the nature, coverage and inclusion of CSR related topics in the curricula of higher educational institutions in Ghana. This implies that the state of ESD in Ghana has not reached a pervasive point to ensure an adequate awareness of issues of sustainability. There is also the need to consider the calls for ESD studies in different culture and location (Manteaw, 2012).

\section{Organisational attractiveness and CSR}

From the literature, several factors which are organisational, work environment and personal attributes were identified as influencing the choice of an organisation over others. Based on those factors the result (see Table 3) shows that the most highly ranked factor is wages and salary, representing $63.6 \%$. This is followed by job security, career prospects, and managerial quality, which constitute $60.8 \%, 52.6 \% 51.2 \%$ respectively. Though the mean scores also confirm these results, the mean score of job security is ranked tops, followed by wages and salary, managerial quality, career prospect, and many more. These findings are consistent with previous studies on the employment benefits of the organization (Duda, 2014; Hiltrop, 1999; Saks et al., 1996), and the attitude of the management (Turban et al., 1998; Goltz \& Giannantonio, 1995).

With regards to CSR related factors, the results show low percentages relative to the other factors. For example, CSR related factors such as shared value, ethical standards, and CRP constituted (43.8\%, $42.2 \%$ and $32.8 \%$ respectively). However, the mean scores on the scale of 1 to 7 are all above five (5), suggesting that the CSR factors also influence the preference for an organisational. Furthermore, the apparent focus on economic 
Table 2 Definition of CSRP from Respondents

\begin{tabular}{lll}
\hline Definition of CSRP & Frequency & Percent \\
\hline Ethical conduct in activities & 228 & 54.4 \\
Complying with existing regulations & 172 & 34.4 \\
Annual reports, sustainability reports & 169 & 33.8 \\
Transparency in operations & 197 & 39.4 \\
Making profits & 117 & 23.4 \\
Environmentally friendly activities & 289 & 57.8 \\
Commitment to employees & 185 & 37.0 \\
Commitment to the public, communities, & 309 & 61.8 \\
and overall society & &
\end{tabular}

dimensions of organisational attractiveness stems from what has been described as low levels of job choice (Albinger and Freeman, 2000), which can be traced to poor economic conditions often associated with developing countries (United Nations, 2013).

\section{CSR disclosure and Organisational attractiveness}

Studies show that CSR disclosures may influence organisational attractiveness (see e.g., Turban \& Greening, 1997). As such, unlike many of the existing studies, this study adopted the elements of CSR disclosure under the GRI guidelines, where $43 \mathrm{CSR}$ items were identified under 6 sub-headings and 3 main headings, namely, economic, environment and social. Results, as reported in Table 4, show that though students rate disclosures on the three (3) major headings high in influencing their preference for an organisation, the influence of disclosures on social and environmental issues are higher than economic issues. This suggests that prospective employees are attracted more by disclosures on the social and environmental dimensions of CSR, but the economic factors are central to their decision to choose one organisation over others.

\section{Summary of findings and conclusion}

This paper explores the relevance of Corporate Social Responsibility Practices (CSRP) of organisations in attracting university students (prospective employees) in a developing country. The emphasis on developing countries has become necessary in recent years due to calls for CSR studies and CSR education in particular in these jurisdictions (Moon \& Orlitzky, 2011; Tilt, 2016).

Firstly, unlike many of the existing studies in this area, this study sought to ascertain the level of CSR awareness among prospective employees. Findings show that the majority of respondents are aware and fairly understand the CSR concept. However, the fact that cumulatively more than $48 \%$ of final year students about to graduate with all the curriculum they have been exposed to, still have little or no idea about CSR raises concern about the growing interests and calls for CSR studies based on evidence from developing countries (Tilt, 2016). Indeed, there is the need for a comprehensive study on CSR education and ESD to among other things, investigate the nature, coverage and inclusion of CSR related topics in the curricula of higher educational institutions to provide the basis for CSR studies.

Secondly, findings show that the factors that lead to organisational attractiveness are those associated with employment benefits (job security, wages and salary,

Table 3 Elements of Organisational Attractiveness

\begin{tabular}{|c|c|c|c|c|c|c|c|c|c|}
\hline \multirow[t]{2}{*}{ FACTORS } & \multicolumn{9}{|l|}{ RANKS } \\
\hline & 1 & 2 & 3 & 4 & 5 & 6 & 7 & Mean & SD \\
\hline & $\mathrm{Fq}(\%)$ & $\mathrm{Fq}(\%)$ & $\mathrm{Fq}(\%)$ & $\mathrm{Fq}(\%)$ & $\mathrm{Fq}(\%)$ & $\mathrm{Fq}(\%)$ & $\mathrm{Fq}(\%)$ & & \\
\hline Common Sense of Direction & $22(4.4)$ & $5(1.0)$ & $11(2.2)$ & $31(6.2)$ & $89(17.8)$ & $115(23)$ & $227(45.4)$ & 5.83 & 1.52 \\
\hline Shared Values & $15(3.0)$ & $5(1.0)$ & $9(1.8)$ & $33(6.6)$ & $90(18.0)$ & $129(25.8)$ & 219(43.8) & 5.88 & 1.39 \\
\hline Similar Ethical Standards & $20(4.0)$ & $7(1.4)$ & $17(3.4)$ & $32(6.4)$ & $75(15)$ & $138(27.6)$ & $211(42.2)$ & 5.79 & 1.52 \\
\hline Friendliness of the recruiter & $37(7.4)$ & $8(1.6)$ & $24(4.8)$ & $44(8.8)$ & $83(16.6)$ & $92(18.4)$ & $212(42.4)$ & 5.5 & 1.80 \\
\hline Pay (wages and salary) & $11(2.2)$ & $4(0.8)$ & $8(1.6)$ & $10(2.0)$ & $58(11.6)$ & $91(18.2)$ & $318(63.6)$ & 6.29 & 1.25 \\
\hline Managerial Quality and relationships & $8(1.6)$ & $5(1.0)$ & $2(0.4)$ & $13(2.6)$ & $82(16.4)$ & 134(26.8) & $256(51.2)$ & 6.16 & 1.16 \\
\hline Long term career prospects & $13(2.6)$ & $7(1.4)$ & $6(1.2)$ & $17(3.4)$ & $73(14.6)$ & $121(24.2)$ & $263(52.6)$ & 6.09 & 1.34 \\
\hline Level of responsibility given at work & $13(2.6)$ & $2(0.4)$ & $6(1.2)$ & $34(6.8)$ & $97(19.4)$ & $127(25.4)$ & $221(44.2)$ & 5.93 & 1.31 \\
\hline Authority given to work & $17(3.4)$ & $3(0.6)$ & $7(1.4)$ & $26(5.2)$ & $92(18.4)$ & $141(28.2)$ & $214(42.8)$ & 5.9 & 1.37 \\
\hline Involvement in decision making & $13(2.6)$ & $4(0.8)$ & $6(1.2)$ & $27(5.4)$ & $81(16.2)$ & $126(25.2)$ & 243(48.6) & 6.02 & 1.32 \\
\hline Marketability & $20(4.0)$ & $6(1.2)$ & $10(2.0)$ & $52(10.4)$ & $100(20.0)$ & $122(24.4)$ & 190(38.0) & 5.66 & 1.50 \\
\hline Job Security & $7(1.4)$ & $3(0.6)$ & $6(1.2)$ & $15(3.0)$ & 48(9.6) & $117(23.4)$ & $304(60.8)$ & 6.32 & 1.13 \\
\hline The level of CSRP disclosures, policies & $36(7.2)$ & $9(1.8)$ & $14(2.8)$ & $43(8.6)$ & 118(23.6) & $116(23.2)$ & 164(32.8) & 5.4 & 1.70 \\
\hline
\end{tabular}

Fq $=$ frequency 
Table 4 CSRP disclosures and Job attraction

\begin{tabular}{|c|c|c|c|c|c|c|c|c|c|}
\hline & \multicolumn{7}{|l|}{ RANKS } & \multirow{3}{*}{ M } & \multirow{3}{*}{ SD. } \\
\hline & 1 & 2 & 3 & 4 & 5 & 6 & 7 & & \\
\hline & $\mathrm{Fq}(\%)$ & $\mathrm{Fq}(\%)$ & $\mathrm{Fq}(\%)$ & $\mathrm{Fq}(\%)$ & $\mathrm{Fq}(\%)$ & $\mathrm{Fq}(\%)$ & $\mathrm{Fq}(\%)$ & & \\
\hline \multicolumn{10}{|l|}{ Economic Factors } \\
\hline Economic performance & $11(2.2)$ & $5(1.0)$ & $7(1.4)$ & $16(3.2)$ & $74(14.8)$ & 158(31.6) & $228(45.6)$ & 6.05 & 1.25 \\
\hline Market presence & $17(3.4)$ & - & $13(2.6)$ & $34(6.8)$ & 93(18.6) & $142(28.4)$ & $201(40.2)$ & 5.83 & 1.39 \\
\hline Indirect Impacts & $32(6.4)$ & $6(1.2)$ & $21(4.2)$ & $53(10.6)$ & 137(27.4) & $121(24.2)$ & $130(26.0)$ & 5.28 & 1.62 \\
\hline Procurement & $24(4.8)$ & $10(2.0)$ & $17(3.4)$ & $71(14.2)$ & $120(24.0)$ & $111(22.2)$ & $147(29.4)$ & 5.35 & 1.58 \\
\hline Attribute mean & & & & & & & & 5.63 & 1.46 \\
\hline \multicolumn{10}{|l|}{ Environmental } \\
\hline Safe raw materials & $10(2.0)$ & $4(0.8)$ & $14(2.8)$ & $35(7.0)$ & 78(15.6) & $146(29.2)$ & 213(42.6) & 5.91 & 1.32 \\
\hline Clean and renewable Energy & $16(3.2)$ & $6(1.2)$ & $6(1.2)$ & $51(10.2)$ & $95(19.0)$ & $125(25.0)$ & $201(40.2)$ & 5.76 & 1.43 \\
\hline Water Conservation & $6(1.2)$ & $6(1.2)$ & $7(1.4)$ & $31(6.2)$ & $73(14.6)$ & 137(27.4) & $240(48.0)$ & 6.06 & 1.22 \\
\hline Biodiversity & $14(2.8)$ & $8(1.6)$ & $15(3.0)$ & $42(8.4)$ & 93(18.6) & $128(25.6)$ & $200(40.0)$ & 5.75 & 1.45 \\
\hline Reduced emissions & 19(3.8) & $15(3.0)$ & $16(3.2)$ & $65(13.0)$ & 95(19.0) & $126(25.2)$ & 164(32.8 & 5.47 & 1.58 \\
\hline Reduced waste & 20(4.0) & $3(0.6)$ & $16(3.2)$ & $50(10.0)$ & $87(17.4)$ & 137(27.4) & 187(37.4) & 5.68 & 1.49 \\
\hline Environmentally safe Products & $8(1.6)$ & $2(0.4)$ & $10(2.0)$ & $34(6.8)$ & $85(17.0)$ & $131(26.2)$ & $230(46.0)$ & 6.00 & 1.24 \\
\hline Compliance with Protection Standards & $8(1.6)$ & $4(0.8)$ & $5(1.0)$ & $42(8.4)$ & 83(16.6) & $130(26.0)$ & $228(45.6)$ & 5.98 & 1.26 \\
\hline Supplier impacts & $17(3.4)$ & $10(2.0)$ & $9(1.8)$ & $42(8.4)$ & $116(23.2)$ & 145(29.0) & $161(32.2)$ & 5.62 & 1.44 \\
\hline Environmental impact grievance channels & $26(5.2)$ & $3(0.6)$ & $12(2.4)$ & $54(10.8)$ & 109(21.8) & $146(29.2)$ & 150(30.0) & 5.51 & 1.53 \\
\hline Attribute mean & & & & & & & & 5.77 & 1.4 \\
\hline \multicolumn{10}{|l|}{ Social-Labour Practices and Decent Work } \\
\hline Employment benefits & $8(1.6)$ & $1(0.2)$ & $6(1.2)$ & $12(2.4)$ & $52(10.4)$ & 132(26.4) & 289(57.8) & 6.30 & 1.11 \\
\hline Labour/Mgt Relations & $7(1.4)$ & $3(0.6)$ & $4(0.8)$ & 15(3.0) & 79(15.8) & 157(31.4) & 235(47.0) & 6.13 & 1.12 \\
\hline Health and Safety & $6(1.2)$ & $2(0.4)$ & - & $14(2.8)$ & $50(10.0)$ & 139(27.8) & 289(57.8) & 6.35 & 1.02 \\
\hline Training and Edu. & $10(2.0)$ & $1(0.2)$ & $6(1.2)$ & $11(2.2)$ & $66(13.2)$ & 133(26.6) & 273(54.6) & 6.23 & 1.17 \\
\hline Diversity and Equal Opportunity & $12(2.4)$ & $3(0.6)$ & $4(0.8)$ & $24(4.8)$ & $76(15.2)$ & 144(28.8) & 237(47.4) & 6.06 & 1.26 \\
\hline Equal Remuneration & $17(3.4)$ & $5(1.0)$ & $8(1.6)$ & $32(6.4)$ & $69(13.8)$ & 118(23.6) & $251(50.2)$ & 5.98 & 1.43 \\
\hline Supplier Assessment for Labour & $21(4.2)$ & $5(1.0)$ & $16(3.2)$ & $40(8.0)$ & $94(18.8)$ & 150(30.0) & 174(34.8) & 5.65 & 1.50 \\
\hline Labour Grievance channels & $17(3.4)$ & $5(1.0)$ & $11(2.2)$ & $40(8.0)$ & $81(16.2)$ & $142(28.4)$ & 204(40.8) & 5.81 & 1.44 \\
\hline Attribute mean & & & & & & & & 6.06 & 1.25 \\
\hline \multicolumn{10}{|l|}{ Social - Human Rights } \\
\hline Investment in Human rights & 15(3.0) & $7(1.4)$ & $10(2.0)$ & $35(7.0)$ & $121(24.2)$ & $121(24.2)$ & 191(38.2) & 5.73 & 1.41 \\
\hline Non-discrimination & $7(1.4)$ & $2(0.4)$ & $4(0.8)$ & $25(5.0)$ & 83(16.6) & 118(23.6) & $261(52.2)$ & 6.15 & 1.16 \\
\hline Association and Bargaining & $11(2.2)$ & - & $11(2.2)$ & $27(5.4)$ & $96(19.2)$ & 138(27.6) & $217(43.4)$ & 5.96 & 1.26 \\
\hline Child Labour & $16(3.2)$ & $3(0.6)$ & $5(1.0)$ & $29(5.8)$ & 112(22.4) & 108(21.6) & $227(45.4)$ & 5.90 & 1.37 \\
\hline Forced Labour & 18(3.6) & $3(0.6)$ & $7(1.4)$ & $24(4.8)$ & 102(20.4) & $117(23.4)$ & $229(45.8)$ & 5.91 & 1.40 \\
\hline Security Practices & $9(1.8)$ & $2(0.2)$ & $8(1.6)$ & $37(7.4)$ & 79(15.8) & 133(26.6) & 233(46.6) & 6.01 & 1.24 \\
\hline Indigenous Rights & $12(2.4)$ & $4(0.8)$ & $14(2.8)$ & $25(5.0)$ & 94(18.8) & 145(29.0) & $206(41.2)$ & 5.89 & 1.33 \\
\hline Supplier Impact & 20(4.0) & $6(1.2)$ & $16(3.2)$ & $40(8.0)$ & $110(22.0)$ & 139(27.8) & 169(33.8) & 5.61 & 1.49 \\
\hline Human Rights Grievance channels & 23(4.6) & $9(1.8)$ & $8(1.6)$ & $39(7.8)$ & 100(20.0) & 135(27.0) & 186(37.2) & 5.67 & 1.54 \\
\hline Attribute mean & & & & & & & & 5.87 & 1.36 \\
\hline \multicolumn{10}{|l|}{ Society } \\
\hline Local Communities & 28(5.6) & $2(0.4)$ & $15(3.0)$ & $46(9.2)$ & 119(23.8) & 133(26.6) & 157(31.4) & 5.51 & 1.55 \\
\hline Anti-corruption & $8(1.6)$ & $3(0.6)$ & $9(1.8)$ & $21(4.2)$ & $92(18.4)$ & $129(25.8)$ & 238(47.6) & 6.05 & 1.22 \\
\hline
\end{tabular}


Table 4 CSRP disclosures and Job attraction (Continued)

\begin{tabular}{|c|c|c|c|c|c|c|c|c|c|}
\hline & \multicolumn{7}{|l|}{ RANKS } & \multirow{3}{*}{ M } & \multirow{3}{*}{ SD. } \\
\hline & 1 & 2 & 3 & 4 & 5 & 6 & 7 & & \\
\hline & $\mathrm{Fq}(\%)$ & $\mathrm{Fq}(\%)$ & $\mathrm{Fq}(\%)$ & $\mathrm{Fq}(\%)$ & $\mathrm{Fq}(\%)$ & $\mathrm{Fq}(\%)$ & $\mathrm{Fq}(\%)$ & & \\
\hline Public Policy & $14(2.8)$ & $6(1.2)$ & $9(1.8)$ & $42(8.4)$ & 108(21.6) & $144(28.8)$ & 177(35.4) & 5.73 & 1.37 \\
\hline Anti-competitive Behaviour & $22(4.4)$ & $8(1.6)$ & $13(2.6)$ & $46(9.2)$ & $123(24.6)$ & 133(26.6) & 155(31.0) & 5.52 & 1.51 \\
\hline Compliance with laws & $11(2.2)$ & $4(0.8)$ & $11(22)$ & $26(5.2)$ & $90(18.0)$ & 133(26.6) & $225(45.0)$ & 5.96 & 1.31 \\
\hline Supplier Impacts & $15(3.0)$ & $4(0.8)$ & $11(2.2)$ & $47(9.4)$ & $117(23.4)$ & $144(28.8)$ & 162(32.4) & 5.65 & 1.38 \\
\hline Grievance channel for Impacts & 16(3.20) & $7(1.4)$ & $9(1.8)$ & $48(9.6)$ & 119(23.8) & $128(25.6)$ & 173(34.6) & 5.65 & 1.43 \\
\hline Attribute mean & & & & & & & & 5.72 & 1.39 \\
\hline \multicolumn{10}{|l|}{ Social Product Responsibility } \\
\hline Customer Health and Safety & $5(1.0)$ & $3(0.6)$ & $7(1.4)$ & $21(4.2)$ & $79(15.8)$ & $112(22.4)$ & 273(54.6) & 6.19 & 1.15 \\
\hline Product and Service Labelling & $12(2.4)$ & $5(1.0)$ & $5(1.0)$ & $32(6.4)$ & 109(21.8) & $123(24.6)$ & 214(42.8) & 5.89 & 1.32 \\
\hline Marketing Communications & $17(3.4)$ & $4(0.8)$ & $8(1.6)$ & $32(6.4)$ & 114(28.8) & $114(28.8)$ & $181(36.2)$ & 5.76 & 1.38 \\
\hline Customer Privacy & $8(1.6)$ & $4(0.8)$ & $8(1.6)$ & $22(4.4)$ & $81(16.2)$ & $130(26.0)$ & $247(49.4)$ & 6.08 & 1.22 \\
\hline Product standards compliance & $8(1.6)$ & $6(1.2)$ & $6(1.2)$ & $17(3.4)$ & 74(14.8) & $146(29.2)$ & 243(48.6) & 6.11 & 1.21 \\
\hline Attribute mean & & & & & & & & 6.01 & 1.25 \\
\hline
\end{tabular}

managerial quality, career prospect, and participation in decision making), and that is consistent with earlier studies (Duda, 2014; Hiltrop, 1999; Saks et al., 1996). In the case of CSR factors, though the results show low percentages relative to the employment benefit factors, the mean scores which are above five (5) indicate that CSR factors also influence prospective employees, thus, largely confirming previous studies (Goltz \& Giannantonio, 1995; Turban \& Greening 1996; Turban et al., 1998; Jones et al., 2014).

Thirdly, the findings based on the influence of CSR disclosures (based on GRI) on organisational attractiveness confirmed the above findings except that students indicated that the influence of disclosures on social and environmental issues are higher than economic issues. This means that organisations can use CSR disclosures, particularly, the social and environmental issues as adverts in their employment drives.

The findings suggest the need for organisations to begin taking cognizance of the growing interest of prospective employees in working for organisations that engage CSR related activities and disclosures. Moreover, the fairly low levels of awareness and understanding of CSR related issues suggest the need for educational institutions to be deliberate in developing the CSR orientation of students and their personal values. This should be done with the aim of equipping them to engage in the systematic processing of CSR related information for comprehensive decision making. It is necessary for the academic curriculum to be modified or restructured to encourage students' understanding and appreciation of CSRP. Also, as suggested by Fernández-Sánchez, et al., (2014), in the area of accreditation of the undergraduate curriculum, some CSR education is needed to reduce the about $48 \%$ of students who stated that they had little and no knowledge about CSR. This will bring about students' perception and attitude that will favour CSRP as well as to enable them to make informed decisions on the organisation to work for. Also, with the growing interest in CSR related factors in attracting talents, there is need to formalize some minimum CSRP by organisations within developing countries. In Ghana, for instance, this can be considered as a part of the recently launched National CSR policy, which focuses on business organisations.

Despite the above, this study suffered some limitations which are commonly associated with the use of a questionnaire. Specifically, there was no room for the openended question to solicit respondents' own definition of CSR. Also, the data collection method lacked the characteristic flexibility of interviews to check misinterpretations by respondents and to seek clarifications. To that end, future studies may adopt a qualitative approach where interviews and focused group discussions will be employed in the data collection. Also, future studies can solicit information on the sources of students' CSR knowledge and how that affects their attraction to organisations. Finally, future studies may explore the relevance of gender and social-cultural factors in organisational attraction.

\section{Endnotes \\ ${ }^{1}$ http://www.ugbs.ug.edu.gh/about-the-school}

\section{Acknowledgements}

The authors are grateful to the respondents for completing the questionnaires. They are also grateful for the comments received from the 2nd International Research Conference - College of Humanities, University of Ghana. 


\section{Authors' contributions}

Both authors made substantial contributions to the paper. EKA specifically collected the data, undertook the initial analysis of data, and later read through the draft manuscript. SNYS conducted further analysis of data to illicit more information. He drafted the manuscript and undertook several revision to get it ready for publications. Both authors read and approved the final manuscript.

\section{Competing interests}

There are no financial and non-financial competing interests so far as this paper is concerned.

\section{Publisher's Note}

Springer Nature remains neutral with regard to jurisdictional claims in published maps and institutional affiliations.

\section{Received: 14 October 2017 Accepted: 4 April 2018}

Published online: 11 April 2018

\section{References}

Aiman-Smith, L., Bauer, T. N., \& Cable, D. M. (2001). Are you attracted? Do you intend to pursue? A recruiting policy-capturing study. J Bus Psychol, 16(2), 219-237.

Backhaus, K. B., Stone, B. A., \& Heiner, K. (2002). Exploringthe relationship between corporate social performance and employer attractiveness. Business \& Society, 41(3), 292-318.

Barrena-Martínez, J., López-Fernández, M., Márquez-Moreno, C., \& RomeroFernández, P. M. (2015). Corporate social responsibility in the process of attracting college graduates. Corp Soc Responsib Environ Manag, 22, 408-423.

Barth, M., Godemann, J., Rieckmann, M., \& Stoltenberg, U. (2007). Developing key competencies for sustainable development in higher education. Int J Sustain High Educ, 8(4), 416-430.

Bebbington, J., Larrinaga-González, C., \& Moneva-Abadía, J. M. (2008). Legitimating reputation/the reputation of legitimacy theory. Account Audit Account J, 21(3), 371-374.

Berthon, P., Ewing, M., \& Hah, L. L. (2005). Captivating company: Dimensions of attractiveness in employer branding. Int J Advert, 24(2), 151-172.

Bhattacharya, C. B., Sen, S., \& Korschun, D. (2008). Using corporate social responsibility to win the war for talent. Sloan Manag Rev, 49(2), 37-44.

Cable, D. M., \& Turban, D. B. (2003). The value of organizational reputation in the recruitment context: A brand-equity perspective. J App/ Soc Psychol, 33(11), $2244-2266$

Carroll, A. (1979). A three-dimensional conceptual model of corporate performance. Acad Manag Rev, 4(4), 497-505.

Carroll, A. B., \& Shabana, K. M. (2010). The business case for corporate social responsibility: A review of concepts, research and practice. Int J Manag Rev, 12(1), 85-105.

Chapman, D. S., Uggerslev, K. L., Carroll, S. A., Piasentin, K. A., \& Jones, D. A. (2005) Applicant attraction to organizations and job choice: A meta-analytic review of the correlates of recruiting outcomes. J App/ Psychol, 90(5), 928-944.

Connelly, B. L., Certo, S. T., Ireland, R. D., \& Reutzel, C. R. (2011). Signaling theory: A review and assessment. J Manag, 37(1), 39-67.

Cooke, F. L., \& He, Q. (2010). Corporate social responsibility and HRM in China: A study of textile and apparel enterprises. Asia Pacific Business Review, 16(3), 355-376.

Dahlsrud, A. (2008). How corporate social responsibility is defined: An analysis of 37 definitions. Corp Soc Responsib Environ Manag, 15(1), 1-13.

Danilovic, M., Hensbergen, M., Hoveskog, M., \& Zadayannaya, L. (2013). Exploring diffusion and dynamics of corporate social responsibility. Corp Soc Responsib Environ Manag, 22, 129-141.

Davis, J. H., Schoorman, F. D., \& Donaldson, L. (1997). Toward a stewardship theory of management. Acad Manag Rev, 22(1), 20-47.

Deephouse, D. L., \& Carter, S. M. (2005). An examination of differences between Organisational legitimacy and Organisational reputation. J Manag Stud, 42(2), 329-360.

Duarte, A. P., Gomes, D. R., \& Gonçalves das Neves, J. (2014). Finding the jigsaw piece for our jigsaw puzzle with corporate social responsibility: The impact of CSR on prospective applicants' responses. Management Research: The Journal of the Iberoamerican Academy of Management, 12(3), 240-258.

Dubbink, W., Graafland, J., \& Van Liedekerke, L. (2008). CSR, transparency and the role of intermediate organisations. J Bus Ethics, 82(2), 391-406.
Duda, J. (2014). The requirements of university students in the employee benefits by a prospective employer: Procedia Economics and Finance 12 130-137. The Czech Republic.

Eddleston, K. A., \& Kellermanns, F. W. (2007). Destructive and productive family relationships: A stewardship theory perspective. J Bus Ventur, 22(4), 545-565.

Evans, W. R., \& Davis, W. D. (2011). An examination of perceived corporate citizenship, job applicant attraction, and CSR work role definition. Business \& Society, 50(30), 456-480.

Feinstein, N. W., Jacobi, P. R., \& Lotz-Sisitka, H. (2013). When does a nation-level analysis make sense? ESD and educational governance in Brazil, South Africa, and the USA. Environ Educ Res, 19(2), 218-230.

Geva, A. (2008). Three models of corporate social responsibility: Interrelationships between theory, research, and practice. Bus Soc Rev, 113(1), 1-41.

Ghobadian, A., Money, K., \& Hillenbrand, C. (2015). Corporate Responsibility Research Past - Present-Future. Group \& Organisation Management, 40(3), 271-294.

Global Reporting Initiative (GRI) G4 https://www.globalreporting.org/resourcelibra ry/GRIG4-Part1-Reporting-Principles-and-Standard-Disclosures.pdf ( $3^{\text {rd }}$ June, 2016).

GNA, (2016). National Corporate Social Responsibility Policy launched. https:// www.newsghana.com.gh/national-corporate-social-responsibility-policylaunched/. Accessed 20 Dec 2017.

Gokuladas, V. K. (2010). Factors that influence first-career choice of undergraduate engineers in software services companies. Career Development International, 15(2), 144-165.

Goltz, S., \& Giannantonio, C. (1995). Recruiter friendliness and attraction to the job: The mediating role of inferences about the organisation. Journal of Vocational Behavior, 46, 109-118.

Gomes, D., \& Neves, J. (2011). Organizational attractiveness and prospective applicants' intentions to apply. Pers Rev, 40(6), 684-699.

Greening, D. W., \& Turban, D. B. (2000). Corporate social performance as a competitive advantage in attracting a quality workforce. Business \& Society, 39(3), 254-280.

Highhouse, S., Thornbury, E. E., \& Little, I. S. (2007). Social-identity functions of attraction to organizations. Organ Behav Hum Decis Process, 103(1), 134-146.

Hong, G., \& Kim, E. (2017). Overcoming country-of-origin image constraints on hiring: The moderating role of CSR. Asian Business \& Management, 16(4-5), 253-271.

Hornsey, M. J. (2008). Social identity theory and self-categorization theory: A historical review. Soc Personal Psychol Compass, 2(1), 204-222.

Huddy, L. (2001). From social to political identity: A critical examination of social identity theory. Political Psychology, 127-156.

Idowu, S. O., Capaldi, N., Fifka, M., Zu, L., \& Schmidpeter, R. (2015). Dictionary of corporate social responsibility. Springer.

Jones, D. A., Willness, C. R., \& Glavas, A. (2017). When corporate social responsibility (CSR) meets organizational psychology: New Frontiers in micro-CSR research, and fulfilling a quid pro quo through multilevel insights. Front Psychol, 8.

Jones, D. A., Willness, C. R., \& Heller, K. W. (2016). Illuminating the signals job seekers receive from an employer's community involvement and environmental sustainability practices: Insights into why most job seekers are attracted, others are indifferent, and a few are repelled. Front Psychol, 7.

Jones, D. A., Willness, C. R., \& Madey, S. (2014). Why are job seekers attracted by corporate social performance? Experimental and field tests of three signalbased mechanisms. Acad Manag J, 57(2), 383-404.

Jones, D. A., Willness, C., \& Macneil, S. (2009). Corporate Social Responsibility and Recruitment: Testing Person-Organisation Fit and Signaling Mechanisms. In Academy of Management Proceedings (Vol. 2009, No. 1, pp. 1-6). Academy of Management.

KPMG, (2015). The currents of change: The KPMG survey of Corporate Responsibility Reporting 2015 available at https://assets.kpmg.com/content/ dam/kpmg/pdf/2016/02/kpmg-international-survey-of-corporateresponsibility-reporting-2015.pdf.

Lee, E. M., Park, S., \& Lee, H. J. (2013). Employee perception of CSR activities: Its antecedents and consequences. J Bus Res, 66, 1716-1724.

Lievens, F., Decaesteker, C., Coetsier, P., \& Geirnaert, J. (2001). Organizational attractiveness for prospective applicants: A person-organisation fit perspective. Appl Psychol, 50(1), 30-51.

Lozano, R., Lukman, R., Lozano, F. J., Huisingh, D., \& Lambrechts, W. (2013). Declarations for sustainability in higher education: Becoming better leaders, through addressing the university system. J Clean Prod, 48, 10-19.

McWilliams, A., Siegel, D. S., \& Wright, P. M. (2006). Corporate social responsibility: Strategic implications. J Manag Stud, 43(1), 1-18. 
Manteaw, O. O. (2012). Education for sustainable development in Africa: The search for pedagogical logic. Int J Educ Dev, 32(3), 376-383.

Matten, D., \& Moon, J. (2008). "Implicit" and "explicit" CSR: A conceptual framework for a comparative understanding of corporate social responsibility. Acad Manag Rev, 33(2), 404-424.

Meister J. (2012).Corporate Social Responsibility: A Lever for Employee Attraction \& Engagements Forbes. Retrieved from http://www.forbes.com/sites/ jeannemeister/2012/06/07/corporate-social-responsibility-a-leverforemployee-attraction-engagement/. Accessed 20 Dec 2017.

Moon, J., \& Orlitzky, M. (2011). Corporate social responsibility and sustainability education: A trans-Atlantic comparison. J Manag Organ, 17(5), 583-603.

Odumeru, J. A., Asabi, O. M., \& Benita, N. (2014). Corporate social responsibility and organisation attractiveness to jobseekers. World Journal of Social Sciences, 4(3), 171-182.

Osagie, E. R., Wesselink, R., Blok, V., Lans, T., \& Mulder, M. (2016). Individual competencies for corporate social responsibility: A literature and practice perspective. J Bus Ethics, 135(2), 233-252.

Pavlova, M. (2012). Teaching and learning for sustainable development: ESD research in technology education. International Journal of Technology Design and Education, 23(3), 733-748.

Pavlova, M. (2009). Conceptualisation of technology education within the paradigm of sustainable development. International Journal of Technology Design and Education, 19(2), 109-132.

Ramasamy, B., \& Ting, H. W. (2004). A comparative analysis of corporate social responsibility awareness. Journal of Corporate Citizenship, (13, 13), 109-123.

Rieckmann, M. (2012). Future-oriented higher education: Which key competencies should be fostered through university teaching and learning? Futures, 44(2), 127-135.

Saks, A., Wiesner, W., \& Summers, R. (1996). Effects of job previews and compensation policy on applicant attraction and job choice. J Vocat Behav, 49, 68-85.

Sekiguchi, T., \& Huber, V. L. (2011). The use of person-organisation fit and person-job fit information in making selection decisions. Organisational Behavior and Human Decision Processes, 116(2), 203-216.

Smith, W. J., Wokutch, R. E., Harrington, K. V., \& Dennis, B. S. (2004). Organizational attractiveness and corporate social orientation: Do our values influence our preference for affirmative action and managing diversity? Business \& Society, 43(1), 69-96.

Story, J., Castanheira, F., Castanheira, F., Hartig, S., \& Hartig, S. (2016). Corporate social responsibility and organizational attractiveness: Implications for talent management. Social Responsibility Journal, 12(3), 484-505.

Strand, R., Levine, R., \& Montgomery, D. (1981). Organizational entry preferences based upon social and personnel policies: An information integration perspective. Organizational Behavior and Human Performance, 27(1), 50-68.

Teo, H. A., \& Poon, T. F. (1994). Career choice of undergraduates and SMEs in Singapore. Int J Career Manag, 6(3), 20-26.

Terry, D. J., Hogg, M. A., \& White, K. M. (1999). The theory of planned behavior: Self-identity, social identity and group norms. The British Journal of Social Psychology, 38, 225.

Tilling, M. V. (2004). Some thoughts on legitimacy theory in social and environmental accounting. Social and Environmental Accountability Journal, 24(2), 3-7.

Tilt, C. A. (2016). Corporate social responsibility research: The importance of context. International journal of corporate social responsibility, 1(1), 2

Tilt, C. A. (2001). The content and disclosure of Australian corporate environmental policies. Account Audit Account J, 14(2), 190-212.

Turban, D. B., \& Keon, T. L. (1993). Organizational attractiveness: An interactionist perspective. J Appl Psychol, 78(2), 184

Turban, D. B., \& Greening, D. W. (1997). Corporate social performance and organizational attractiveness to prospective employees. Acad Manag J, 40(3), 658-672

Turban, D., Forret, M., \& Hendrickson, C. (1998). Applicant attraction to firms: Influences of organisation reputation, job and Organisational attributes, and recruiter behaviors. Journal of Vocational Behaviour, 52, 24-44.

UNESCO. (2009). Education for sustainable development and climate change. Policy Dialogue, 4 (UNESCO Doc No ED2009/WS/10) Retrieved from http:// unesdoc.unesco.org/images/0017/001791/179122e.pdf.

UNESCO. (2014). Shaping the future we want: UN decade of education for sustainable development (2005-2014) final report. Paris: France.

Wood, D. J. (1991). Corporate social performance revisited. Acad Manag Rev, 16(4), $691-718$
Wade, R., \& Parker, J. (2008). EFA-ESD dialogue: Educating for a sustainable world. UNESCO.

Wals, A. E. (2014). Sustainability in higher education in the context of the UN DESD: A review of learning and institutionalization processes. J Clean Prod, $62,8-15$.

Yang, K., \& Yu, T. (2014). Person - organisation fit, effects on organisational attraction: A test of an expectations- based model. Organisational Behaviour and Human Decision Process, 124, 75-94.

\section{Submit your manuscript to a SpringerOpen ${ }^{\circ}$ journal and benefit from:}

- Convenient online submission

- Rigorous peer review

- Open access: articles freely available online

- High visibility within the field

- Retaining the copyright to your article

Submit your next manuscript at $\gg$ springeropen.com 